\title{
GAS EXCHANGES IN PEACH PALMS AS A FUNCTION OF THE SPAD CHLOROPHYLL METER READINGS ${ }^{1}$
}

\author{
MARIA LUIZA SANT'ANNA TUCCI², VALÉRIA APARECIDA MODOLO ${ }^{3}$, \\ NORMA DE MAGALHÃES ERISMANN ${ }^{4}$, EDUARDO CARUSO MACHADO 5
}

ABSTRACT - The close relationship between the chlorophyll-meters readings and the total chlorophyll and nitrogen contents in leaves, has allowed their evaluation both in annual and perennial species. Besides, some physiological events such as the $\mathrm{CO}_{2}$ assimilation have also been estimated by chlorophyll meters. This work was carried out aiming to evaluate the gas exchanges of peach palms as a function of the chlorophyll SPAD-Meter readings. Three year-old peach palms from Yurimaguas, Peru were studied in Ubatuba, SP, Brazil, spaced $2 \times 1 \mathrm{~m}$ in area under a natural gradient of organic matter which allowed four plots to be considered, according to the peach palms leaves colors, from light yellow to dark green. The SPAD readings and the stomatal frequency of leaflets were evaluated. The photosynthetic photon flux density (PPFD, $\mu \mathrm{mol}$ $\left.\mathrm{m}^{-2} \mathrm{~s}^{-1}\right)$, the leaf temperature $\left(\mathrm{T}_{\text {leaf }},{ }^{\circ} \mathrm{C}\right)$, the $\mathrm{CO}_{2}$ assimilation $\left(\mathrm{A}, \mu \mathrm{mol} \mathrm{m} \mathrm{m}^{-2} \mathrm{~s}^{-1}\right)$, the stomatal conductance $\left(g_{s}\right.$,

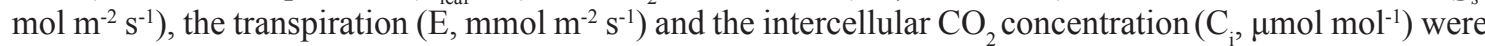
evaluated with a portable infrared gas analyzer (LCA-4, ADC BioScientific Ltd., Great Amwell, U.K.). A linear increase in the $\mathrm{CO}_{2}$ assimilation as a function of the SPAD readings $\left(\mathrm{y}=-0.34+0.19 \mathrm{x}, \mathrm{R}^{2}=0.99\right)$, indicates that they can be a rapid and cheap complementary method to evaluate in peach palms some important physiological events, such as $\mathrm{CO}_{2}$ assimilation.

Index Terms: Bactris gasipaes Kunth, $\mathrm{CO}_{2}$ assimilation, stomatal conductance.

\section{TROCA GASOSA EM PUPUNHA COMO FUNÇAO DE LEITURAS EM CLOROFILOMETRO}

RESUMO - A estreita correlação entre leituras medidas com clorofilômetros portáteis e os teores de clorofila total e de nitrogênio em folhas têm permitido que esses teores tanto em espécies anuais como perenes sejam estimados por meio desses equipamentos. Da mesma forma, alguns eventos fisiológicos, como assimilação de $\mathrm{CO}_{2}$, têm também sido estimados. Este trabalho teve o objetivo de avaliar as trocas gasosas em pupunheiras, em função das leituras realizadas em clorofilômetro SPAD-Meter. Foram estudas em Ubatuba-SP, Brasil, pupunheiras de três anos, originárias de Yurimaguas, Peru, plantadas em espaçamento $2 \times 1 \mathrm{~m}$, em área apresentando gradiente natural de matéria orgânica, fato que permitiu a consideração de quatro plots cada um, apresentando pupunheiras de coloração distinta variando do amarelo-claro ao verde-escuro. Foram avaliadas as leituras SPAD e a frequência estomática dos folíolos. A densidade de fluxo de fótons fotossintéticos (DFFF, $\left.\mu \mathrm{mol} \mathrm{m}{ }^{-2} \mathrm{~s}^{-1}\right)$, a temperatura das folhas $\left(\mathrm{T}_{\text {follha }},{ }^{\circ} \mathrm{C}\right)$, a assimilação de $\mathrm{CO}_{2}\left(\mathrm{~A}, \mu \mathrm{mol} \mathrm{m} \mathrm{m}^{-2} \mathrm{~s}^{-1}\right)$, a condutância estomática $\left(g_{s}, \mathrm{~mol} \mathrm{~m}^{-2} \mathrm{~s}^{-1}\right)$, a transpiração $\left(\mathrm{E}, \mathrm{mmol} \mathrm{m} \mathrm{s}^{-2}\right)$ e a concentração intercelular de $\mathrm{CO}_{2}$ $\left(\mathrm{C}_{\mathrm{i}}, \mu \mathrm{mol} \mathrm{mol}{ }^{-1}\right)$ foram avaliadas pelo analisador portátil por radiação infravermelha (LCA-4, ADC BioScientific Ltd., Great Amwell, U.K.). Correlação linear da assimilação de $\mathrm{CO}_{2}$, em função das leituras SPAD $\left(y=-0.34+0.19 x, R^{2}=0.99\right)$, indicou que o clorofilômetro SPAD-Meter pode ser um meio complementar, rápido e barato de se estimar importantes eventos fisiológicos em pupunheiras, como a assimilação de $\mathrm{CO}_{2}$. Termos para indexação: Bactris gasipaes Kunth, assimilação de $\mathrm{CO}_{2}$, condutância estomática.

\footnotetext{
${ }^{1}$ Trabalho Sinfruit 157 - Simpósio Internacional de Fruticultura - Avanços na Fruticultura (17 a 21 Outubro) ${ }^{2}$ Dr., Scientific Researcher of Horticulture Centre, Instituto Agronômico (IAC). Av. Theodureto de Almeida Camargo 1500, CEP 13075-630, Campinas-SP, Brazil

${ }^{3}$ Dr., Scientific Researcher of Ecophysiology and Biophysics Centre, Instituto Agronômico (IAC), Av. Barão de Itapura 1481, CEP 13020902, Campinas-SP, Brazil
} 


\section{INTRODUCTION}

The Amazonian palm peach palm (Bactris gasipaes Kunth), besides the high quality heart-of-palm, bears nutritive fruits highly consumed by populations from its natural habitat, as sources of carbohydrates and vitamins.

In São Paulo state, Brazil the peach palm growing area for heart-of-palm production is ca. 3.700 ha (Anefalos et al., 2007) and is expanding. In the peach palm germplasm banks of Instituto Agronômico (IAC)/APTA, studies have been carried out concerning the matrix plants characterization, as well as the nutritional requirements for fruits production (MODOLO et al., 2010).

Contrarily to what occurs in its natural habitat, in the São Paulo state subtropical conditions, the peach palm has to face climate seasonality, with evident effects on its physiology, that have been studied majorly concerning the $\mathrm{CO}_{2}$ assimilation and the vegetative growth. Concerning the vegetative growth, Tucci et al. (2007) observed lower growth rates throughout the cold winter months and higher ones in summer. In parallel, the $\mathrm{CO}_{2}$ assimilation was lower in the winter months (TUCCI et al., 2010), what have been attributed by the authors to the lower night temperatures throughout the winter.

Besides the climate, mainly temperature and air vapor pressure deficit $\left(\mathrm{VPD}_{\text {air }}\right)$ among other factors, the $\mathrm{CO}_{2}$ assimilation rate is modulated by the plant nutritional status majorly by nitrogen, essential to plant metabolism, once it is a constituent of proteins and nucleic acids (KOSLOWSKY; PALLARDY, 1997). Actually, the nitrogen deficiency usually decreases photosynthesis, more than other macronutrients, and high linear correlations between $\mathrm{CO}_{2}$ assimilation and leaves nitrogen content have been observed in a number of perennial species (Koslowsky e Pallardy, 1997).

Nitrogen plays a crucial role in peach palms development. Deenik et al. (2000), emphasize the fact that peach palms show significant response to nitrogen fertilization. Positive influences of nitrogen were observed on aspects of the crop such as: seedlings growth (LA TORRACA et al., 1984); increase of aerial biomass (BOVI et al., 1998; BOVI et al., 2000; MOLINA et al., 2002; RAMOS et al., 2004), increase of the offshoots number per plant and of the main stem diameter (BOVI et al., 2002) and increase of root density (BOVI et al., 1999). The need of attending the peach palm nitrogen requirements is crucial and so, the detection of a lack of it by means of a rapid diagnosis is interesting, aiming to correct it before yield losses occur.
Symptoms of N deficiency in peach palms were related by La Torraca et al. (1984); Falcão et al. (1998); Bovi et al. (1998) and Molina (1999), including leaves of light green color, a decrease in the palm vigor, older leaves chlorosis, yellowing of all leaves in severe cases, weak and undeveloped offshoots and susceptibility to soil water deficit.

The peach palm nutritional status has been evaluated by means of foliar analysis and comparisons with the suitable values for the species. However, the analysis are expensive, lasting, and sometimes they do not allow corrections before losses in production occur, and a rapid and cheaper method to perform $\mathrm{N}$ periodic evaluations would be interesting. The process becomes feasible by using digital chlorophyll-meters, which have been widely used in the rapid and non-destructive evaluations of leaves total chlorophyll, as well as of the $\mathrm{N}$ status, because of the close relationship between them.

Among the authors who reported linear relationships between chlorophyll-meters readings and the total chlorophyll content in leaves, are Schaper and Chacko (1991) for the following fruit trees: cashew, lychee, jackfruit, durian, annona and starfruit, and Fanizza et al. (1991) for the grapevine. Concerning the relationships between chlorophyll meters and plant N status, Neilsen et al. (1995), considered the use of the chlorophyll meter SPAD-502 interesting, to determine the response of apple trees cultivars to the $\mathrm{N}$ fertirrigation.

Besides the chlorophyll and nitrogen content, the use of chlorophyll-meters has been also extended, to estimate photosynthesis and other physiological aspects of crops. Gas exchanges measurements and chlorophyll-meters readings can give useful information on the relationships between them (SCHAPER; CHACKO, 1991; MARKWELL et al., 1995; YAMAMOTO et al., 2002). According to Fanizza et al. (1991), the non-destructive nature of chlorophyll-meters readings, makes the equipment particularly useful in studies on photosynthesis and senescence in grapevines, which depend on the continued monitoring of the chlorophyll content and degradation. Rajcan et al. (1999) observed a positive correlation between the chlorophyll-meter readings and the soluble carbohydrates content, in senescent corn leaves. Torres Neto et al. (2002) observed in papaya, relationships between the chlorophyll $a$ fluorescence, important indicative of the performance of the photochemical of photosynthesis, and the chlorophyll-meter readings.

Regarding studies on palms of economic importance, Cristancho et al. (2011) correlated the chlorophyll-meter readings with the foliar area and 
the $\mathrm{CO}_{2}$ assimilation in oil palms (Elaeis guineensis Jacq.) grown under high aluminum content. In boron deficient coconuts (Cocos nucifera L.), Pinho et al. (2010) correlated the chlorophyll-meter readings and photosynthesis. As for peach palms, Tucci et al. (2006) observed seasonal variations in the leaves chlorophyll-meter readings, as well as variations among the leaves ontogenetic levels.

This work was carried out aiming to evaluate the chlorophyll-meter readings on leaves of peach palms growing under a natural fertility gradient, correlating the equipment readings with the $\mathrm{CO}_{2}$ assimilation, the transpiration rate, the stomatal conductance, the instantaneous and intrinsic water efficiencies, as well as with the leaves instantaneous carboxylation efficiency. Stomatal frequencies on both leaflets surfaces were also evaluated.

\section{MATERIAL AND METHODS}

\section{Plant Material}

Studied plants belong to the Putumayo landrace (Yurimaguas) and were obtained from seeds collected at the peach palm germplasm bank, maintained by Instituto Agronomico (IAC)/APTA at its Experimental Stations. Plants were spaced $2 \times 1 \mathrm{~m}$, by the time of this study they were three years old, and had been harvested one time, since the beginning of the experiment. Peach palms had been cultivated under a natural gradient of organic matter through soil top-layer and a visual observation of the palms, propitiated the classification of them into four plots, according to the color of leaves, as follows: Plot 1, peach palms presenting intense chlorosis, leaves color light-yellow; Plot 2, peach palms presenting less intense chlorosis, leaves color greenish-yellow; Plot 3, leaves color light green; Plot 4, plants presenting leaves color green intense, as usually occurs in peach palm crops properly fertilized.

\section{Location}

The trial was located in a private farm in Ubatuba ( $23^{\circ} 27^{\prime}$ S, $45^{\circ} 04^{\prime} \mathrm{W}, 6$ m alt.), São Paulo, Brazil, in a region originally covered by the Atlantic Forest, with mean annual temperature and rainfall of about $20.8^{\circ} \mathrm{C}$ and $2,841 \mathrm{~mm}$, respectively, no water deficit, potential evapotranspiration of $992 \mathrm{~mm}$ and water surplus 1849 mm (ORTOLANI et al., 1995). The soil was an Allic Alluvial (Udifluvents), sandy-textured.

\section{Stomata counting}

Lamina stomatal frequency was determined on the abaxial and adaxial surfaces for two leaflets of the medium part of leaf +2 of four plants randomly selected (pinnate leaves) in each plot. The stomatal frequency was determined from impressions collected from the leaf blade. A thin layer of clear cellulose acetate (nail polish) was applied, and the impressions were examined at a magnification of 250x on a Zeiss optical microscope. Stomatal counts were made at ten different locations on each imprint. Plants were sampled after the gas exchanges measurements.

\section{$S P A D$ readings}

Chlorophyll-meter readings were evaluated by means of a chlorophyll-meter SPAD-Meter (Soil and Plant Analyses Development), Minolta 502, Japan. The equipment provides readings which correspond to the intensity of the leaves green color, that is, to the total chlorophyll content in leaves (MALAVOLTA et al., 1997). Measurements were performed in July, 2001, at 10:00 a.m. in four plants per plot, on a leaflet of the medium part of leaf +2 , the second fully expanded leaf, from the top, according to Tomlinson criteria (TOMLINSON, 1990). On each leaflet the SPAD readings were performed on the proximal, distal, as well as on the medium part of them.

\section{Gas exchanges}

It was not possible to reach the fronds, because of the height of the canopies. Therefore, leaves were detached from the palms. After cutting the leaf, gas exchange measurements were performed immediately on a leaflet from the medium part of the leaf, according to Prado et al. (2001) and Gomes and Prado (2007). Gas exchange measurements were taken on July, 2001 from 10 to 11 a.m. The photosynthetic

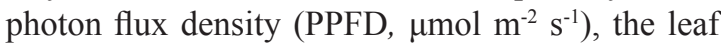
temperature $\left(\mathrm{T}_{\text {leaf }},{ }^{\circ} \mathrm{C}\right)$, the $\mathrm{CO}_{2}$ assimilation $(\mathrm{A}, \mu \mathrm{mol}$ $\left.\mathrm{m}^{-2} \mathrm{~s}^{-1}\right)$, the stomatal conductance $\left(g_{s}, \mathrm{~mol} \mathrm{~m}^{-2} \mathrm{~s}^{-1}\right)$, the transpiration $\left(\mathrm{E}, \mathrm{mmol} \mathrm{m} \mathrm{m}^{-2} \mathrm{~s}^{-1}\right)$ and the intercel-

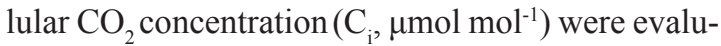
ated with a portable infrared gas analyzer (LCA-4, ADC BioScientific Ltd., Great Amwell, U.K.). The instantaneous water use efficiency $\left(\mathrm{A} / \mathrm{E}, \mu \mathrm{mol} \mathrm{CO}_{2}\right.$ $\left.\mathrm{m}^{-2} \mathrm{~s}^{-1} / \mathrm{mmol} \mathrm{H}_{2} \mathrm{O} \mathrm{m}^{-2} \mathrm{~s}^{-1}\right)$, the intrinsic water use efficiency $\left(\mathrm{A} / \mathrm{g}_{\mathrm{s}}, \mu \mathrm{mol} \mathrm{CO} \mathrm{m}^{-2} \mathrm{~s}^{-1} / \mathrm{mol} \mathrm{m}^{-2} \mathrm{~s}^{-1}\right)$ and the instantaneous carboxylation efficiency $(\mathrm{A} / \mathrm{Ci}, \mu \mathrm{mol}$ $\left.\mathrm{CO}_{2} \mathrm{~m}^{-2} \mathrm{~s}^{-1} / \mathrm{Pa}^{-1}\right)$ were calculated from $\mathrm{A}, \mathrm{E}, \mathrm{g}_{\mathrm{s}}$ and $\mathrm{Ci}$ values. Measurements were taken on the adaxial surface of a sunlit leaflet, on the medium part of the second completely expanded leaf $($ leaf +2$)$.

\section{Statistics}

Means were compared by Tukey test at 5\%, and regression analysis and curve fitting were performed by the program Microcal Origin 6.0. 


\section{RESULTS AND DISCUSSION}

\section{Climate}

Evaluations were carried out on a typical winter day for the region, and from 10:00 to 11:00 a.m. when evaluations were performed, the air temperature was $22 \pm 1^{\circ} \mathrm{C}$, the air relative humidity, $90 \pm$ $5 \%$, the $\mathrm{VPD}_{\text {air }}$ ca. $0.5 \mathrm{kPa}$, and the maximum PPFD around $1300 \mathrm{umol} \mathrm{m}^{-2} \mathrm{~s}^{-1}$. However, at the time of the assessments the sky became cloudy and the PPFD was $360 \pm 15 \mathrm{umol} \mathrm{m}^{-2} \mathrm{~s}^{-1}$. The leaf temperature $\left(\mathrm{T}_{\text {leaf }}\right)$ (Fig. 1A) was ca. $24^{\circ} \mathrm{C}$ for the plants from plots 1,2 and 3, differing significantly of leaves from plot 4, which presented lower $\mathrm{T}_{\text {leaf }}$, ca. $21^{\circ} \mathrm{C}$, possibly due to a higher E (Fig. 1B), showed by the leaves of higher SPAD readings (Table 1).

It is worth mentioning that the Ubatuba region on the northern São Paulo state coast represents one of the most suitable peach palm growing regions in the state, once there is no annual water deficit and therefore the $\mathrm{VPD}_{\text {air }}$, important to the peach palm photosynthesis modulation (Tucci et al, 2010) remains low throughout the year, with no need for irrigation (BOVI, 1998).

\section{$S P A D$ readings and stomata counting}

The difference in the color of leaves observed among Plots was confirmed by the SPAD readings (Table 1), once the results showed a typical change in leaf color and morphology among plots, the later represented by the difference in the stomatal frequency among leaves of the four Plots (Table 2). The SPAD readings, higher on leaves of Plot 4 , showed significant differences among leaves of plants from all plots, regardless the leaflet part considered. As for the leaflet medium portion where the gas exchanges measurements were performed, increasing SPAD readings were observed on leaves from Plot 1 to 4, corresponding to 3.1 and 55.4, respectively. On leaflets portions proximal and distal, there were also significant differences, the data varying from 6.3 for plot 1 to 55.5 for Plot 4 and from 5.9, for Plot 1 to 45.2, for Plot 4, for the proximal and distal regions, respectively. SPAD readings of leaves from Plot 4 , measured on the proximal and on the medium portion of leaflets are in agreement with those related by Tucci et al. (2006), when observing the SPAD readings variation as a function of leaves ontogeny. The authors related average SPAD readings of 56, for leaves $+2,+3 \mathrm{e}+4$ of peach palms growing in the so-called 'planalto paulista', in São Paulo state. SPAD readings observed in winter, spring and summer on leaves of the same ontogeny were lower.

The stomatal frequency on the leaflets adaxial surface (Table 2) was significant lower than on abaxial surface, showing a higher value of 9.4 stomata $\mathrm{mm}^{-2}$ on the dark green leaves of Plot 4 . The results are consistent with Tucci et al. (2000) who observed on peach palm leaves a frequency significant higher on leaflets abaxial surfaces. The later was higher on leaflets of plants from Plot 3, corresponding to 65.6 stomata $\mathrm{mm}^{-2}$, what was $26 \%$ higher than 51.9 stomata $\mathrm{mm}^{-2}$ observed on leaflets from plants showing a severe chlorosis. The abaxial surfaces of leaves from Plots 1,2 e 3 showed a stomatal frequency higher than 60 stomata $\mathrm{mm}^{-2}$. It is interesting to note that Tucci et al. (2000) observed on the leaflets abaxial surfaces of peach palms, growing under climate conditions different from those of this experiment an average of 101.4 stomata $\mathrm{mm}^{-2}$. A hypothesis for the high difference, can be found in Cutter (1986), who mentioned the fact that, stomatal frequencies, under some circumstances, can be altered by factors such as, light intensity and humidity of the growing sites, at the moment of stomata initiation.

\section{Gas exchanges}

The $\mathrm{CO}_{2}$ assimilation (Fig 1E) showed significant variation $(\mathrm{P} \leq 0,05)$ among plots increasing linearly from plants of Plot 1 to those of Plot 4 , corresponding to 0.3 and $10.1 \mu \mathrm{mol} \mathrm{m}^{-2} \mathrm{~s}^{-1}$, respectively, paralleling the SPAD readings (Fig 1F). It is important to note that $\mathrm{g}_{\mathrm{s}}$ (Fig 1C) showed a different dynamics in comparison to assimilation, once their values on plants of Plots 2, 3 e 4 do not differ, showing a $g_{\mathrm{s}}$ ca. $0.54 \mathrm{mmol} \mathrm{m}^{-2}, \mathrm{~s}^{-1}$, whereas on leaves of Plot 1 gs was $0.30 \mathrm{mmol} \mathrm{m}^{-2}, \mathrm{~s}^{-1}$. So, for the same stomatal conductance, leaves from Plot 4 showed $\mathrm{CO}_{2}$ assimilation 3.5 times higher than those from Plot 2 and 1.7 times higher than those from Plot 3.

On the other hand the $\mathrm{C}_{i}$ values (Fig $1 \mathrm{D}$ ) remained practically unchanged among plots, indicating that the assimilation of plants from Plots 1,2 and 3 was not limited by the $\mathrm{CO}_{2}$ diffusion through the stomata, therefore not meaning a stomatal constraint but probably a metabolic one. This becomes clearer when one observes the ratios $\mathrm{A} / \mathrm{g}_{\mathrm{s}}$ and $\mathrm{A} / \mathrm{C}_{\mathrm{i}}$ (Fig 2 $\mathrm{B}, \mathrm{C})$. The later indicates the instantaneous carboxylation efficiency of the enzyme ribulose 1,5 bisfosfato carboxilase/oxigenase (Rubisco). Thus, once the $\mathrm{C}_{\mathrm{i}}$ values remained high on leaves of plants of every plot, the lower assimilation of plants from Plots 1,2 e 3 may have been due to the lower Rubisco content in leaves of plants from plots of lower SPAD readings what indicates lower leaf nitrogen and proteins. The later have higher $\mathrm{N}$ content than other plant organs, because of the higher Rubisco content required for $\mathrm{CO}_{2}$ assimilation (LAWLOR, 2001), because of the 
soluble proteins of the Calvin cycle, as well as of the thylakoid membranes (KOSLOWSKY; PALLARDY, 1997). Thus, a nitrogen deficiency can result in low photosynthetic efficiency chloroplasts, highlighting the close relationship between $\mathrm{CO}_{2}$ assimilation and leaves $\mathrm{N}$ and protein content. Besides that, $\mathrm{A} / \mathrm{g}_{\mathrm{s}}$ and $\mathrm{A} / \mathrm{E}$ (Fig $2 \mathrm{~A}$ ) also decreased in leaves of plants from Plots from 4 to 1 , indicating that for similar values of $g_{s}$ the assimilation was more efficient on the dark green leaves of Plot 4 . The results indicate that the apparent chlorophyll and $\mathrm{N}$ deficiencies on plants of Plots 1, 2, and 3, caused metabolic constraints to the $\mathrm{CO}_{2}$ assimilation on plants from these plots more intense on plants of Plot 1 which presented the lowest SPAD readings.

A linear increase in the $\mathrm{CO}_{2}$ assimilation as a function of the SPAD readings (Fig. 3), fitted by the equation $\mathrm{y}=-0.34+0.19 \mathrm{x}, \mathrm{R}^{2}=0.99$, indicating that evaluations carried out by means of chlorophyll meters readings on peach palm leaves can be an important, rapid and non-destructive complementary method to evaluate the chlorophyll and nitrogen leaves content and also some aspects of important physiological events such as $\mathrm{CO}_{2}$ assimilation.

It is important to note that further studies should be performed under the different edaphoclimatic conditions where peach palms have been grown in São Paulo state, Brazil.

TABLE 1 - SPAD readings of peach palm leaves measured on different parts of the leaflets, proximal region, medium region and distal region.

\begin{tabular}{cccc}
\hline Plots & \multicolumn{3}{c}{ SPAD Readings } \\
\hline & $\begin{array}{c}\text { Proximal } \\
\text { region }\end{array}$ & $\begin{array}{c}\text { Medium } \\
\text { region }\end{array}$ & Distal region \\
\hline 1 & $6.30 \mathrm{~d}$ & $3.07 \mathrm{~d}$ & $5.85 \mathrm{~d}$ \\
2 & $22.29 \mathrm{c}$ & $16.50 \mathrm{c}$ & $10.98 \mathrm{c}$ \\
3 & $35.06 \mathrm{~b}$ & $33.03 \mathrm{~b}$ & $33.55 \mathrm{~b}$ \\
4 & $55.50 \mathrm{a}$ & $55.40 \mathrm{a}$ & $45.24 \mathrm{a}$ \\
\hline
\end{tabular}

Means followed by the same letter in the vertical position do not differ by Tukey test at $5 \%$ probability.

TABLE 2 - Stomatal frequency of peach palm leaflets on the abaxial and the adaxial surfaces.

\begin{tabular}{ccc}
\hline Plots & Abaxial & Adaxial \\
\hline 1 & $51.95 \mathrm{c}$ & $4.55 \mathrm{a}$ \\
2 & $62.95 \mathrm{ab}$ & $5.20 \mathrm{a}$ \\
3 & $65.65 \mathrm{a}$ & $5.25 \mathrm{a}$ \\
4 & $60.55 \mathrm{~b}$ & $9.40 \mathrm{~b}$ \\
\hline
\end{tabular}

Means followed by the same letter in the vertical position do not differ by Tukey test at $5 \%$ probability. 


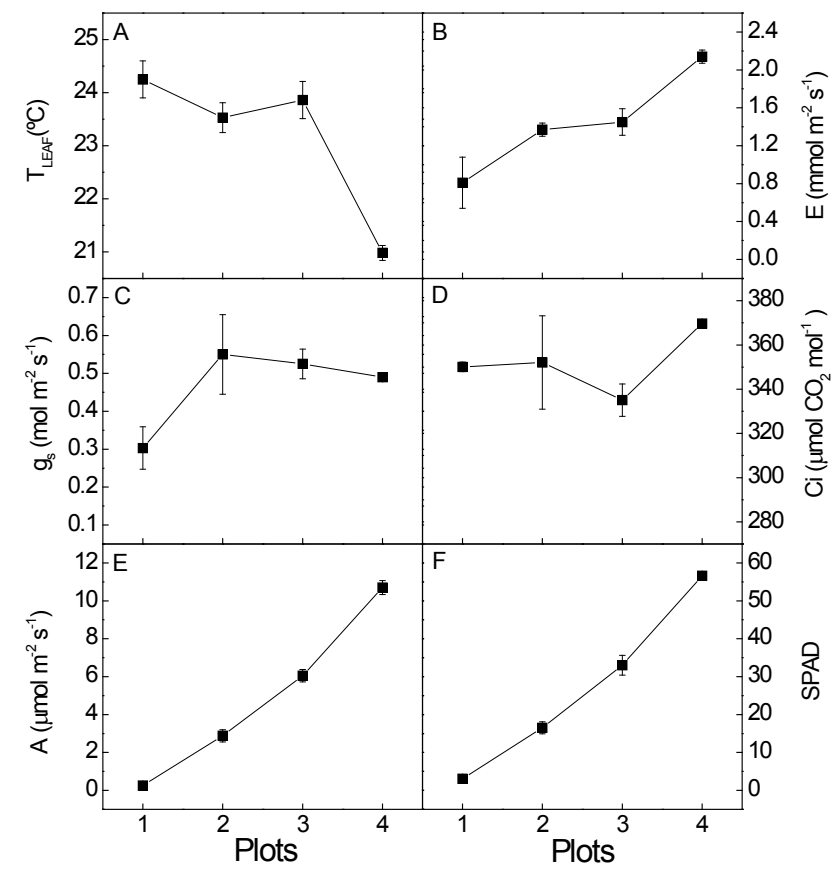

FIGURE 1 - Values of leaf temperature (Tleaf, A), transpiration (E, B), stomatal conductance (gs, C), intercellular $\mathrm{CO} 2$ concentration $(\mathrm{Ci}, \mathrm{D})$, leaf $\mathrm{CO} 2$ assimilation (A, B) and SPAD chlorophyll readings (SPAD, F) of peach palms, on a typical winter day in Ubatuba, SP, Brazil. Each symbol represents the mean value of 4 plants.

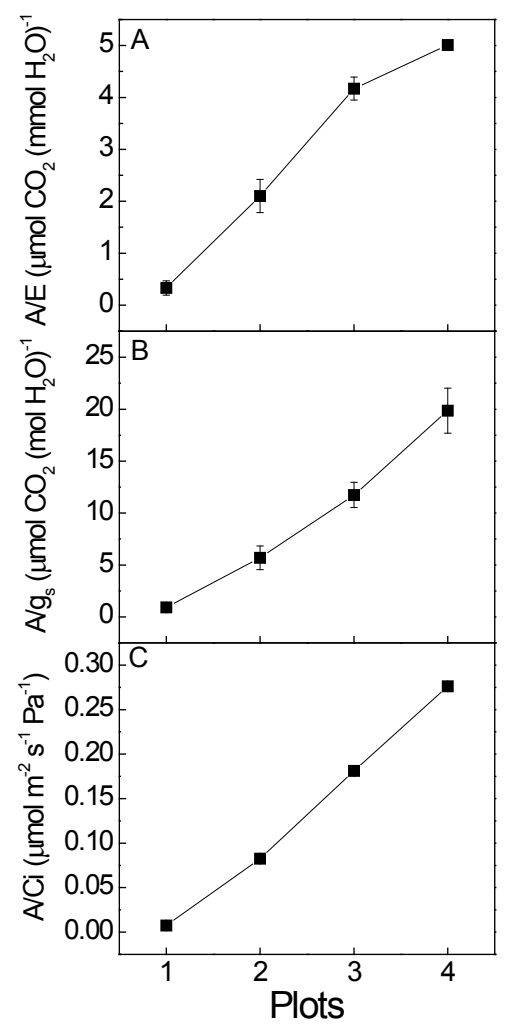

FIGURE 2 - Values of the instantaneous water efficiency (A/E, A), the intrinsic water efficiency (A/gs, B) and carboxylation capacity $(\mathrm{A} / \mathrm{Ci}, \mathrm{C})$ of peach palm leaves, on a typical winter day in Ubatuba, SP, Brazil. Each symbol represents the mean value of 4 plants. 


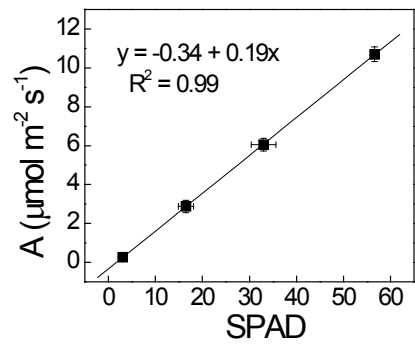

FIGURE 3 - Three year-old peach palm leaves $\mathrm{CO}_{2}$ assimilation as a function of the SPAD chlorophyll readings. Each symbol represents the mean value of 4 plants.

\section{CONCLUSION}

The observed linear increase in the $\mathrm{CO}_{2}$ assimilation as a function of the SPAD readings ( $\mathrm{y}=$ $-0.34+0.19 \mathrm{x}, \mathrm{R}^{2}=0.99$ ), indicates that they can be a rapid and cheap complementary method to evaluate, in peach palms, some important physiological events, such as $\mathrm{CO}_{2}$ assimilation.

\section{REFERENCES}

ANEFALOS, L.C.; MODOLO, V.A.; TUCCI, M.L.S. Expansão do cultivo da pupunheira no Vale do Ribeira-SP, Brasil, 2002-2006. Informações Econômicas, São Paulo, n. 37, p.37-43, 2007.

BOVI, M.L.A.; BASSO, L.C.; TUCCI, M.L.S. Avaliação da atividade in vivo da fosfatase ácida e do crescimento de progênies de pupunheira cultivadas em duas doses de nitrogênio e fósforo. Revista Brasileira de Ciência do Solo, Campinas, v. 22, p. 427-434, 1998.

BOVI, M.L.A.; GODOY JR., G.; SPIERING, S.H. Respostas de crescimento da pupunheira à adubação NPK. Scientia Agricola, Piracicaba, v. 59, n. 1, p. 161-166, 2002.

BOVI, M.L.A.; LAMBAIS, M.R.; TUCCI, M.L.S.; GODOY JR., G.; SPIERING, S.H. Biomass accumulation and vesicular-arbuscular mycorrhizal colonization in pejibaye (Bactris gasipaes) as a function of NPK fertilization. Acta Horticulturae, The Hague, v. 513, n.3, p. 153-168, 2000.

BOVI, M.L.A.; SPIERING, S.H.; BARBOSA, A.M.M. Densidade radicular de progênies de pupunheira em função de adubação NPK. Horticultura Brasileira, Brasília, v.17, n.3, p.186-193, 1999.
CRISTANCHO, R.J.A.; HANAFI, M.M.; SYED OMAR, S.R.; RAFII, M.Y. Variations in oil palm (Elaeis guineensis Jacq.) progeny response to high concentrations in solution culture. Plant Biology, Stuttgart, v. 13, n. 2, p. 333-342, 2011.

CUTTER, E.G. Epiderme. In: CUTTER, E.G. Anatomia vegetal: células e tecidos. 2.ed. São Paulo: Livraria Roca, 1986. p. 97-145

DEENIK, A.; ARES, A.; YOST, R.S. Fertilization response and nutrient diagnosis in peach palm (Bactris gasipaes): a review. Nutrient Cycling in Agroecosystems, Dordrecht, v. 56, p.195-207, 2000.

FANIZZA, G.; DELLA GATTA, C.; BAGNULO, C. A non-destructive determination of leaf chlorophyll in Vitis vinifera. Annals of Applied Biology, Warwick, v. 119, p. 203-205, 1991.

GOMES, F.P.; PRADO, C.H.B.A. Ecophysiology of coconut palm under water stress. Brazilian Journal of Plant Physiology, Piracicaba, v. 19, n. 4, p. 377391, 2007.

KOSLOWSKY, T.T.; PALLARDY, S.G. Physiology of woody plants. 2.ed. San Diego: Photosynthesis, 1997. cap. 5 , p.87-134.

LA TORRACA. S.M.; HAAG, H.P.; DECHEN, A.R. Nutrição mineral de frutiferas tropicais I. Sintomas de carências nutricionais em pupunha. O Solo, Piracicaba, v. 76, n. 1, p. 53-56, 1984.

MODOLO, V.A.; TUCCI, M.L.S.; SPIERING, S.H. Growth charachterization in palms progenies under Subtropical conditions. In: INTERNATIONAL HORTICULTURAL CONGRESS, 28.. 2010, Lisboa. Anais... p.619. 
MALAVOLTA, E.; VITTI, G.C.; OLIVEIRA, S.A. Avaliação do estado nutricional das plantas: princípios e aplicações. 2.ed. Piracicaba: Potafós, 1997. 319p.

MOLINA, E. Fertilización del pejibaye para palmito: research report for the short course on peach palm production. San Jose: Centro de Investigaciones Agronómicas, Universidad de Costa Rica, 1999.

MOLINA, E.; ALVARADO, A.; SMYTH, T.J.; BONICHE, J.; ALPÍZAR, D.; OSMOND, D. Respuesta del pejibaye para palmito (Bactris gasipaes) al nitrógeno en andisoles de Costa Rica. Agronomia Costarricense, San Jose, v. 26, n. 2, p. 31-42, 2002.

MARKWELL, J.; OSTERMAN, J.C.; MITCHELL, J.L. Calibration of the Minolta SPAD-502 leaf chlorophyll meter. Photosynthesis Research, Dordrecht, v. 46, p. 467-472, 1995.

NEILSEN, D.; HOGUE, E.J.; HERBERT, L.C.; PARCHOMCHUK, P.; NEILSEN, G.H. Use of rapid techniques for estimating the $\mathrm{N}$ status of fertirrigated apple trees. Acta Horticulturae, The Hague, v. 383, p. 211- 218, 1995.

ORTOLANI, A.A.; CAMARGO, M.B.P.; PEDRO JUNIOR, M.J. Normais climatológicas dos postos meteorológicos do Instituto Agronômico: 1. Centro Experimental de Campinas. Campinas: Instituto Agronômico, 1995. 13p. (Boletim Técnico)

PINHO, L.G.R.; CAMPOSTRINI, E.; MONNERAT, P.H.; PIRES NETTO, A.T.; MARCIANO, C.R.; SOARES, Y.J.B. Boron deficiency affects gas exchange and photochemical efficiency (JPI test parameters) in green dwarf coconut. Journal of Plant Nutrition, new York, v. 33, n. 3, p. 439-451, 2010.

PRADO, C.H.B.A.; PASSOS, E.E.M.; MORAES, J.A.P.V. Photosynthesis and water relations of six tall genotypes of Cocos nucifera in wet and dry seasons. South African Journal of Botany, Pretoria, n. 67, p. 169-176, 2001.

RAJCAN, I.; DWYER, L.M.; TOLLENAAR, M. Note on relationship between leaf soluble carbohydrate and chlorophyll concentrations in maize during leaf senescence. Field Crops Research, Amsterdam, v. 63, p. $13-17,1999$.
RAMOS, A.; BOVI, M.L.A.; FOLEGATTI, M.V.; DIOTTO, A.V. Efeitos da fertirrigação sobre a produção de palmito da pupunheira. Horticultura Brasileira, Brasília, v. 22, n. 4, p. 734-739, 2004.

SCHAPER, H.; CHACKO, E.K. Relation between extractable chlorophyll and portable chlorophyll meter readings in leaves of eight tropical and subtropical fruit tree species. J. of Plant Physiology, Washington, v. 138, p. 674-677, 1991.

TOMLINSON, P.B. The structural biology of palms. Oxford: Clarendon Press, 1990. 463p.

TORRES NETO, A.; CAMPOSTRINI, E.; OLIVEIRA, J.G.; YAMANISHI, O.K. Portable chlorophyll meter for the quantification of photosynthetic pigments, nitrogen and the possible use for assessment of the photochemical process in Carica papaya $\mathrm{L}$. Brazilian Journal of Plant Physiology, Piracicaba, v.14, n.3, p. 203-210, 2002.

TUCCI, M.L.S.; BOVI, M.L.A.; MACHADO, E.C.; SPIERING, S.H. Seasonal variation in growth of peach palms cultivated in containers under subtropical conditions. Scientia Agricola, Piracicaba, v. 64, n. 2, p. 138-146, 2007.

TUCCI, M.L.S.; BOVI, M.L.A.; MACHADO, S.; SPIERING, S.H. Stomatal frequency and size in leaves of pejibaye. Acta Horticulturae, The Hague, v. 516, p. $145-154,2000$

TUCCI, M.L.S.; ERISMANN, N.M.; MACHADO, E.C.; RIBEIRO, R.V. Diurnal and seasonal variation in photosynthesis of peach palms grown under subtropical conditions. Photosynthetica, Praga, v. 48, n. 3, p. 421-429, 2010.

YAMAMOTO, A.; NAKAMURA, T.; ADU-GYAMFI, J.J.; SAIGUSA, M. Relationship between chlorophyll content in leaves of sorghum and pigeon pea determined by extraction method and by chlorophyll meter. Journal of Plant Nutrition, New York, v. 25, n. 10, p. 2295-2301, 2002. 